\title{
同济医学院海外校友总会奖学金暨美捷登一一同济医学院海外校 友总会生物医学奖学金颁奖座谈
}

\author{
张雅琦 \\ 武汉美捷登生物科技有限公司
}

2018 年 4 月 24 日晚, 同济医学院海外校友总 会奖学金暨美捷登——同济医学院海外校友总会生 物医学奖学金颁奖座谈会在医学院报告厅举行。同 济医学院海外校友总会主席向惠云、副主席夏华向、 医学院党委副书记邓静萍、综合办公室主任柳会祥、
医学学生工作处处长熊享涛、医学研究生处副处长 李强、校友办公室主任柯育萍、医学学生工作处教 育管理办公室主任王绪武等出席会议。会议由综合 办公室副主任许齐主持。

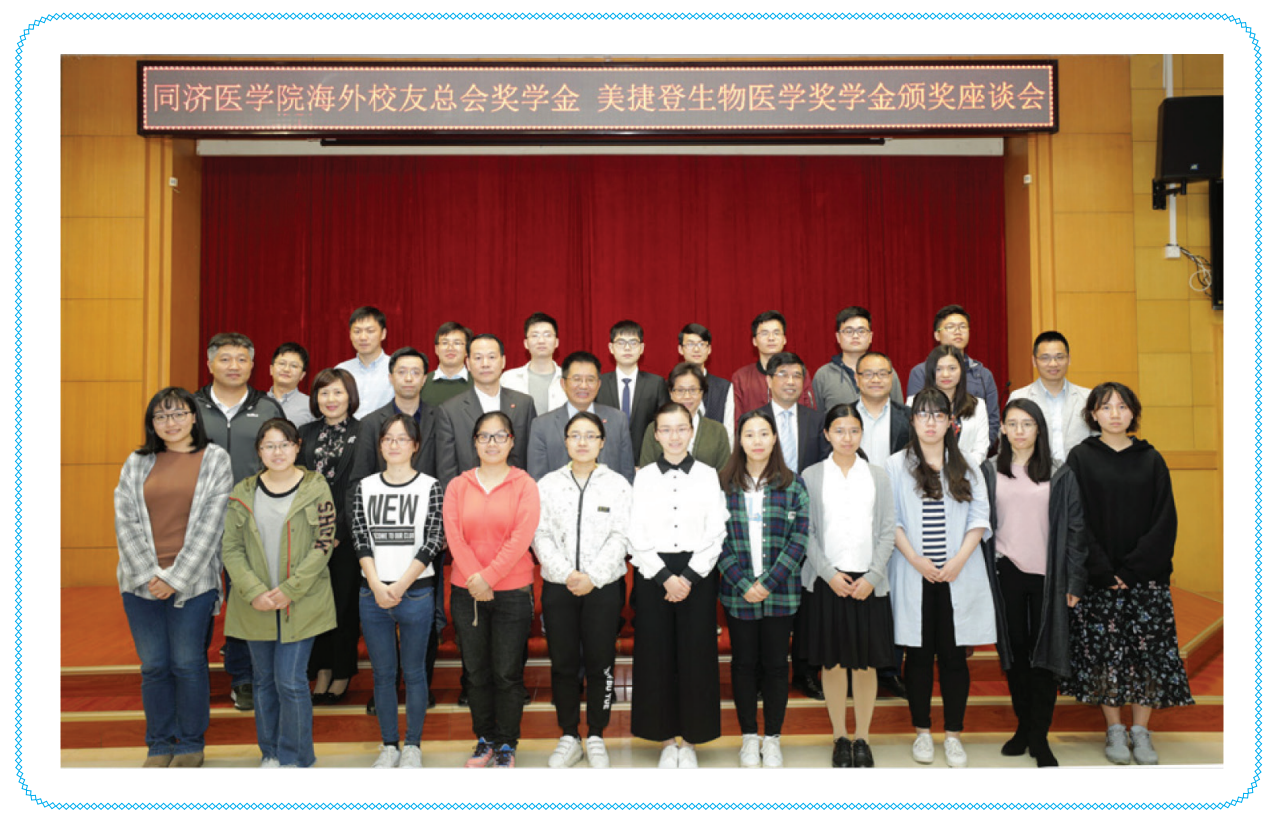

会议伊始, 向惠云、夏华向分别宣读了 2018 年同济医学院海外校友总会奖学金和 2018 年美捷 登一一同济医学院海外校友总会生物医学奖学金获 奖者名单, 并向获奖同学表示祝贺。邓静萍、向惠云、 夏华向、柳会祥、熊享涛和李强为所有获奖者颁奖。

2017 年同济医学院海外校友总会奖学金获奖代 表余泽和 2017 年美捷登——同济医学院海外校友 总会生物医学奖学金获奖代表聂樱丽分别发言，他 们由衷感谢海外校友总会对同济学子的关爱和支持, 表示将发扬同济精神, 追求卓越, 砥砺奋进, 将来 为奉献社会、回报母校。

2018 年海外校友总会奖学金获奖代表王雨欣和 2018 年美捷登——同济医学院海外校友总会生物医 学奖学金获奖代表陈海红分别发言, 在表示感谢的 同时表达了刻苦学习、积极向善、回报社会的决心。
海外校友总会主席向惠云、副主席夏华向在聆 听各位学生代表的发言后对各位获奖者表示祝贺, 并感谢那些为奖学金评选工作辛勤劳动的老师们。 夏华向回顾了他的求学和科研经历, 对参会学生提 出三点期望: 专心学业, 刻苦钻研; 与导师建立良 好关系, 积极、主动了解导师的研究领域; 在科研 道路上不要走捷径, 远离各种学术不端行为。

最后, 医学院党委副书记邓静萍作总结讲话。 她代表医学院党委和行政对海外校友总会及美捷登 生物科技有限公司回馈母校、关心教育、慷慨助学 的行为表示崇高敬意和衰心感谢, 对获奖同学表示 热烈祝贺。希望同学们珍惜荣誉, 继续努力, 用更 优异的成绩回报母校、服务社会。 